\title{
Effect of directly acting anti-viral agents on immunological imprints in chronic HCV-4a patients: interleukin-10 and vascular endothelial growth factor genes expression level
}

Iman S. Naga ${ }^{1 *}$ D, Amel Abdel Fattah Kamel ${ }^{2}$, Said Ahmed Ooda ${ }^{3}$, Hadeer Muhammad Fath Elbab ${ }^{2}$ and Rania Mohamed El-Sharkawy ${ }^{2}$

\begin{abstract}
Background: Hepatitis C virus infection is a global health challenge with Egypt being one of the highly affected countries. IL-10 has been suggested as a suitable marker to assess necroinflammation and to monitor the progression of liver damage. Vascular endothelial growth factor (VEGF) is a potent angiogenic factor playing a central role in many physiological as well as pathological processes. Several factors can be predictive of the response to treatment and achievement of SVR; some of which are host-related, and others are virus-related. The gene expression of IL-10 and VEGF have multiple effects for treatment response. The aim of the present work was to study the effect of treatment with directly acting agents (DAA) on the expression of VEGF and IL-10 genes in chronic hepatitis C virus-infected Egyptian genotype-4a patients. Twenty-five HCV subjects where evaluated for IL10 and VEGF gene expression before and after treatment with DAA.
\end{abstract}

Results: IL-10 expression was downregulated in 92\% of the cases. VEGF expression was heterogeneous showing spreading of values along a wide range with $64 \%$ of the cases being downregulated.

Conclusion: DAAs do not completely reverse the immunological imprints established upon chronic HCV infection.

Keywords: HCV, VEGF, IL-10, Gene expression, Genotype-4, DAA

\section{Background}

Hepatitis $\mathrm{C}$ virus (HCV) infection is a global health challenge with Egypt being one of the highly affected countries [1]. HCV genome exhibits significant genetic variability which leads to its classification into 7 major genotypes and up to 67 different subtypes. This genetic variability affects the response to treatment and the virus

\footnotetext{
* Correspondence: iman.naga@alexu.edu.eg; imannaga80@gmail.com ${ }^{1}$ Department of Microbiology, Medical Research Institute, University of Alexandria, Alexandria, Egypt

Full list of author information is available at the end of the article
}

capability to escape the immune surveillance [2]. Genotype 4 is the most common genotype in Egypt [3].

In 2018, a meta-analysis for HCV viremic rate among the Egyptian population indicated that $\mathrm{HCV}$ prevalence was estimated by $11.9 \%$ among the general population; $67 \%$ of them are chronically infected and are in need for treatment [4].

Both innate and adaptive immune responses are essential for viral clearance. The innate response is the first line of defense during infection [5]. Cytokines play an important role in viral clearance, inflammation, regeneration, and fibrosis. Interleukin 10 (IL-10) and vascular

\section{Springer Open}

( ) The Author(s). 2021 Open Access This article is licensed under a Creative Commons Attribution 4.0 International License, which permits use, sharing, adaptation, distribution and reproduction in any medium or format, as long as you give appropriate credit to the original author(s) and the source, provide a link to the Creative Commons licence, and indicate if changes were made. The images or other third party material in this article are included in the article's Creative Commons licence, unless indicated otherwise in a credit line to the material. If material is not included in the article's Creative Commons licence and your intended use is not permitted by statutory regulation or exceeds the permitted use, you will need to obtain permission directly from the copyright holder. To view a copy of this licence, visit http://creativecommons.org/licenses/by/4.0/. 
endothelial growth factor (VEGF) are key players in the immune response against $\mathrm{HCV}$ infection. Both are seen elevated in patients with $\mathrm{HCV}$, cirrhosis, and $\mathrm{HCC}$ and their levels are associated with disease progression and prognosis [6]. IL-10 can also be used as a marker to assess necroinflammation and to monitor the progression of liver damage [7]. High levels of IL-10 are associated with Th-2-like response which leads to viral persistence and chronicity. Moreover, IL-10 inhibits Th-1-like response that is responsible for viral clearance after acute infection [8].

The adaptive immune response through $\mathrm{CD} 4+\mathrm{T}$ cells has a central role in induction of anti-viral immune response against viral infection which can be subdivided according to two predominant profiles referred to as $\mathrm{T}$ helper 1 (Th1)-like and T helper 2 (Th2)-like responses. Th1-like responses include the secretion of IL-2, TNF- $\alpha$, and IFN- $\gamma$ which are required for generation of cytotoxic $\mathrm{T}$ lymphocytes and activation of natural killer (NK) cells, while Th2-like responses produce IL-4 and IL-10, which inhibit development of the Th1 response [9]. In early $\mathrm{HCV}$ infection, those who clear the infection have significant Th1 responses with high IFN- $\gamma$ and IL-2, while those who progress to chronicity have a significantly high magnitude of IL-10 and significantly higher ratio of IL-10 to IFN- $\gamma$ production early in infection and along the course of the disease [10].

VEGF is a potent angiogenic factor playing a central role in many physiological as well as pathological processes. VEGFs exert their effects by activation of different signaling pathways stimulating endothelial cell proliferation and migration and increasing the vascular permeability $[11,12]$. It is a powerful mitogen for microvascular and macrovascular endothelial cells. VEGF reduces hepatocellular tight junction (TJ) integrity and hepatocellular polarity through a VEGFR-2 dependent pathway [13]. The increased hepatic angiogenesis in chronic HCV could provide the molecular basis for liver carcinogenesis and contribute to the increased risk of HCC in patients with cirrhosis on top of HCV [14].

"The goal of treatment of $\mathrm{HCV}$-infected persons is to reduce mortality and liver-related health adverse consequences, including end-stage liver disease and hepatocellular carcinoma, by the achievement of virologic cure as evidenced by a sustained virologic response." as recommended by the EASL-IDSA. The introduction of the directly acting anti-viral agents (DAAs) in the treatment of chronic $\mathrm{HCV}$ infections has led to dramatic improvement in outcome of HCV-infected patients [15].

The present work aimed to study the effect of treatment with directly acting agents (DAA) on the expression of VEGF and interleukin-10 genes in chronic HCVinfected patients in Alexandria, Egypt.

\section{Methods}

After the approval of the Ethical Committee of the Medical Research Institute, 25 chronic HCV genotype-4infected patients were selected from the Department of Experimental and Clinical Internal Medicine, Medical Research Institute, Alexandria University. An informed consent was taken from each patient. The $25 \mathrm{HCV}$ positive patients were assessed before and after the end of DAA treatment. Exclusion criteria included coinfection with HBV infection, co-morbidities with renal or cardiac diseases, having any malignancies, and any immunological disorders.

The $25 \mathrm{HCV}$-positive patients were diagnosed by positive anti-HCV test result and confirmed by measuring the viral load by real-time polymerase chain reaction (PCR). The patients received sofosbuvir/ledipasvir once daily for 12 weeks. Virological response was assessed at the end of treatment. In this prospective study, the following was performed for all patients:

\section{Complete physical examination}

Abdominal examination for signs of hepatic failure as ascites. Abdominal ultrasound to confirm the presence or absence of cirrhosis and any liver mass if present and Child-Pugh classification [16].

\section{Blood sampling}

Sampling was performed at baseline and at the end of treatment. Ten milliliters of venous blood was withdrawn from each patient and divided into different vacutainers for molecular studies, coagulation studies, and complete blood count. Sera was separated for the determination of the concentrations of serum levels of albumin [17], total and direct bilirubin [18], and serum activities of the enzymes alanine and aspartate aminotransferases using fully automated chemistry analyzer Beckman AU400 [19, 20]. Also, plasma prothrombin activity (PT) was done [21].

\section{Determination of HCV viral load}

Viral RNA was extracted from patients' sera using QIAamp viral RNA mini spin Kit (Qiagen') according to manufacturer's instructions. The extracted viral RNA was used as a template for $\mathrm{HCV}$ viral load determination before initiation of treatment and 12 weeks after treatment using Artus HCV QS-RGQ-PCR Kit (Qiagen ${ }^{\circ}$ ) and real-time PCR machine MX3000 TM (Stratagene) according to manufacturer's instructions [22].

\section{Determination of HCV genotype}

$\mathrm{HCV}$ genotype via amplification, sequencing, and nucleotide blasting of NS5b domain. Briefly, cDNA strand was synthesized from HCV RNA using RevertAid First Strand cDNA Synthesis Kit (Thermo Scientific) using 
random hexamer primers provided with the kit. NS5b domain was amplified using nested PCR primers JA 230 CTACCATCATGGCTAA(A/G)AA(C/T)GAGGT JA 233 ATGATGTTATGAGCTCCA(A/G)GTC(A/G)TA JA 231 TATGA(C/T)ACCCGCTG(C/T)TTTGAC 50 JA 232 CCTGGTCATAGCCTCCGTGAA. The PCR reaction was performed in $25 \mu \mathrm{l}$ final reaction containing $2 \times$ DreamTaq green PCR master mix (Thermo Scientific, USA) and $5 \mu \mathrm{M}$ of each primer and $1 \mu \mathrm{l}$ of cDNA or first amplification. The thermal cycling consisted of 35 cycles of denaturation at $95{ }^{\circ} \mathrm{C}$ for $30 \mathrm{~s}$, annealing at 50 ${ }^{\circ} \mathrm{C}$ for $30 \mathrm{~s}$ and extension at $72{ }^{\circ} \mathrm{C}$ for $30 \mathrm{~s}$, and preceded by 1 cycle of initial denaturation at $95{ }^{\circ} \mathrm{C}$ for $5 \mathrm{~min}$ and followed by 1 cycle of final extension at $72{ }^{\circ} \mathrm{C}$ for $5 \mathrm{~min}$. The same reaction was used for the second amplification (nested) in $50 \mu \mathrm{L}$ final reaction volume containing $1 \mu \mathrm{L}$ of the first amplification product as a template. The purified NS5b PCR products were sequenced using the BigDye Terminator V 3.1 Cycle Sequencing Kit (Applied Biosystems) on the automated sequencer ABI prism 310 genetic analyzers (Applied Biosystems). For determination of HCV genotypes and subtypes, NS5b sequencing results were analyzed using a HCV BLAST free online tool from HCV sequence database (https://hcv.lanl.gov/ content/sequence/BASIC_BLAST/basic_blast.html).

\section{IL-10 and VEGF relative gene expression:}

Peripheral blood mononuclear cells (PBMC) were isolated from anticoagulated blood by Ficoll-Paque ${ }^{\text {тм }}$ method then total RNA was purified from mononuclear cells using Qiagen RNeasy Mini Kit Spin Technology according to manufacturer's instructions. The concentration of RNA was determined using Nano Drop Thermo Spectrophotometry (Thermo Scientific) by measuring the absorbance at $260 \mathrm{~nm}$ A260. The purity of RNA was assessed using ratio A260/A280 ratio. Ratio between 1.7 and 1.9 was considered acceptable. Reverse transcription of 1 ug of RNA and effective genomic DNA elimination was performed by the Quantitect Reverse Transcription kit according to manufacturer's instructions then quantification of IL-10, VEGF, and GAPDH genes was performed using SBR-green real-time PCR. QuantiTect Primer Assays (Qiagen ${ }^{\circledR}$ ) was used for accurate real-time quantification of target RNA. The reaction was performed in $20 \mu \mathrm{l}$ final volume containing $10 \mu \mathrm{l}$ Quantitect sybr green PCR Master Mix, $2 \mu$ l Quantitect primer assay, and $2.5 \mu \mathrm{l}$ template cDNA on real-time PCR machine MX3000 TM (Stratagene). The reaction took place under the following thermal profile: initial incubation at $50{ }^{\circ} \mathrm{C}$ for $15 \mathrm{~min}$ to activate the DNA polymerase. This was followed by 45 cycles of 3 PCR-step amplification, denaturation at $94{ }^{\circ} \mathrm{C}$ for $15 \mathrm{~s}$, followed by annealing at $57{ }^{\circ} \mathrm{C}$ for IL-10 and $60{ }^{\circ} \mathrm{C}$ for VEGF for $30 \mathrm{~s}$, and followed by extension at $72{ }^{\circ} \mathrm{C}$ for $30 \mathrm{~s}$, with real-time fluorescence detection.

\section{Calculation of relative gene expression}

Relative expression of target genes (IL-10, VEGF) was calculated using the comparative CT method $\left(2^{-\Delta \Delta C T}\right.$ method) [23]. CT values of the target genes were normalized against the CT value of housekeeping gene (GAPDH). The fold changes after treatment was compared to the control group (before treatment) which was set to 1 [24].

\section{Calculation of platelet ratio index (APRI) and fibrosis- (FIB-) 4 scores}

Platelet ratio index (APRI) and fibrosis- (FIB-) 4 indexes were calculated using simple mathematical formulas as follows [25]:

APRI : (AST $[$ level] $/$ AST $[$ upper limit of normal] $/$ platelet count $[109 / \mathrm{L}]) \times 100$

For APRI, cut-off value of $<0.5$ rules out fibrosis while $\geq 1$ was assigned for marked fibrosis and $\geq 2$ for cirrhosis.

$$
\begin{aligned}
\text { FIB-4 } & : \text { age }[\text { years }] \times(\text { AST }[\mathrm{U} / \mathrm{L}] \text { platelets } \times 109 / \mathrm{L}] \\
& \times \operatorname{ALT} 1 / 2[\mathrm{U} / \mathrm{L}]) .
\end{aligned}
$$

For FIB-4, a cut-off value of $<1.45$ rules out advanced fibrosis while $\geq 3.25$ was assigned for marked fibrosis.

\section{Statistical analysis}

Data were fed to the computer and analyzed using IBM SPSS software package version 20.0. (Armonk, NY: IBM Corp.). Qualitative data were described using number and percent. The Kolmogorov-Smirnov test was used to verify the normality of distribution. Quantitative data were described using range (minimum and maximum), mean, standard deviation, and median. Significance of the obtained results was judged at the $5 \%$ level. The Student $t$ test was used for normally distributed quantitative variables to compare between two studied groups while Mann-Whitney test was used for abnormally distributed quantitative variables. Correlations between quantitative continuous variables parameters were evaluated by linear regression with analysis of Pearson's coefficients.

\section{Results}

A total of $25 \mathrm{HCV}$ genotype-4-infected patients were enrolled in the present study; all of which (100\%) were treatment-naïve cases. Females represented 52\% (13/25) while males were $48 \%(12 / 25)$ and their ages ranged from 17 to 65 years.

There is a statistically significant difference between the ALT and AST activity as well as prothrombin activity (INR) before and after treatment in the studied cases 
( $p=0.0003, p=0.0001, p=0.022$, respectively). There is no correlation between the viral load and ALT and AST activity, albumin, bilirubin level (total and direct), or the studied hematological parameters before treatment (Table 1).

Child-Pugh score, APRI, and FIB-4 were calculated for all cases enrolled in the present study before treatment to estimate the severity of liver injury and the majority of the patients were categorized as Child-Pugh class (A) $88 \%(22 / 25)$, while class (B) were $12 \%(3 / 25)$, and none were classified as class (C). Additionally, APRI and FIB-4 were calculated for all cases in the present study as a non-invasive marker for assessment of hepatic fibrosis or cirrhosis before and after treatment. Before treatment, APRI ranged from 0.108 to 2.43 with a mean of 0.87 while FIB-4 ranged from 0.27 to 6.49 with a mean of 2.20. After treatment, APRI ranged from 0.214to 0.987 with a mean of 0.44 while FIB-4 ranged from 0.27 to 4.88 with a mean of 1.60 . The difference between the APRI and FIB-4 scores before and after treatment was

Table 1 Hematological, chemical profile, and viral load of HCV patients before and after DAA treatment

\begin{tabular}{|c|c|c|c|}
\hline & Before treatment & After treatment & $p$ value \\
\hline \multicolumn{4}{|l|}{ ALT (U/L) } \\
\hline Min-max & $13-135$ & $4-35$ & $0.0003^{*}$ \\
\hline Mean & 46.40 & 21.08 & \\
\hline \multicolumn{4}{|l|}{ AST (U/L) } \\
\hline Min-max & $8-124$ & $16-35$ & $0.0001^{*}$ \\
\hline Mean & 43.96 & 21.96 & \\
\hline \multicolumn{4}{|c|}{ Albumin (g/dl) } \\
\hline Min-max & $2.8-5.2$ & $3.5-4.8$ & 0.3310 \\
\hline Mean & 3.98 & 4.04 & \\
\hline \multicolumn{4}{|c|}{ Total bilirubin (mg/dl) } \\
\hline Min-max & $0.3-3.05$ & $0.3-1.2$ & 0.406 \\
\hline Mean & 0.73 & 0.67 & \\
\hline \multicolumn{4}{|c|}{ Direct bilirubin (mg/dl) } \\
\hline Min-max & $0.1-2.14$ & $0.1-0.6$ & 0.155 \\
\hline Mean & 0.35 & 0.26 & \\
\hline \multicolumn{4}{|c|}{ Platelets count $\left(\times 10^{3} / \mu \mathrm{l}\right)$} \\
\hline Min-max & $40-304$ & $55-266$ & 0.481 \\
\hline Mean & 178.08 & 177.28 & \\
\hline \multicolumn{4}{|l|}{ PT (INR) } \\
\hline Min-max & $1-1.9$ & $1-1.2$ & $0.022^{*}$ \\
\hline Mean & 1.18 & 1.08 & \\
\hline \multicolumn{4}{|c|}{ HCV load ( $\left.\times 10^{5} \mathrm{IU} / \mathrm{L}\right)$} \\
\hline Min-max & $0.241-130$ & Undetectable & - \\
\hline Mean & 13.22 & & \\
\hline
\end{tabular}

*Statistically significant at $p \leq 0.05$ found statistically significant $(p=0.002, p=0.048$ for APRI and FIB-4, respectively).

The majority of $\mathrm{HCV}$ patients (80\%) had a viral load ranging between $>10^{5}-<10^{7} \mathrm{IU} / \mathrm{ml}$. The remaining $20 \%$ had a viral load $<10^{5}$. NS5b region was successfully amplified and sequenced in all 25 patients included in this study. The $25 \mathrm{HCV}$ patients involved in this study were genotyped as $\mathrm{HCV}$ genotype 4a.

As regards the relative expression of IL-10 (Fig. 1), $92 \%(23 / 25)$ of the cases showed downregulated expression and only $2(8 \%)$ showed upregulated expression. As for the relative expression of VEGF (Figure 2), 64\% (16/ 25 ) of the cases showed downregulated expression while $36 \%(9 / 25)$ of the cases showed upregulated expression (Table 2).

Correlation between IL-10 expression and the liver functions, hematological parameters, viral load, and calculated fibrosis scores before treatment shows a strong positive correlation with the viral load $(r=0.721, p=$ 0.0001) while other parameters show no correlation, while correlation between VEGF expression and liver functions, hematological parameters, viral load, and calculated fibrosis scores before treatment shows a positive correlation with AST activity $(r=0.573, p=0.003)$ as well as with the viral load $(r=0.488, p=0.013)$ while other parameters show no correlation (Table 3 ).

Correlation between IL-10 and VEGF expression and the liver functions (AST, ALT, bilirubin total and direct, albumin), hematological parameters (platelet count, INR), viral load, and calculated fibrosis scores (APRI and FIB-4) after treatment shows no correlation with any of the mentioned parameters.

\section{Discussion}

The use of DAAs for the treatment of viral hepatitis has led to dramatic improvement in outcome of $\mathrm{HCV}$ infected patients. They target 3 main parts of viral particle NS3/4A protease, NS5A, and NS5B RNAdependent polymerase [26].

In the current study, all $\mathrm{HCV}$ patients received sofosbuvir-based regimen for 12 weeks. The results showed that $100 \%$ of the cases $(25 / 25)$ achieved SVR by the end of the treatment course confirmed by an undetectable PCR viral load. This is consistent with other studies that reported high SVR on sofosbuvir-based regimen. El Raziky et al. [27] had presented his results from a phase II open-label study (OSIRIS) conducted in Egypt on 63 patients with/without cirrhosis and has reported $100 \%$ SVR-12 for both groups. Similar results were reported by Lawitz et al. (2015) [28], Feld et al. [29], and Gayam et al. (2018) [30].

Although $\mathrm{HCV}$ RNA monitoring during $\mathrm{HCV}$ treatment has been a standard practice, aminotransferases (ALT and AST) monitoring is also important to assess 


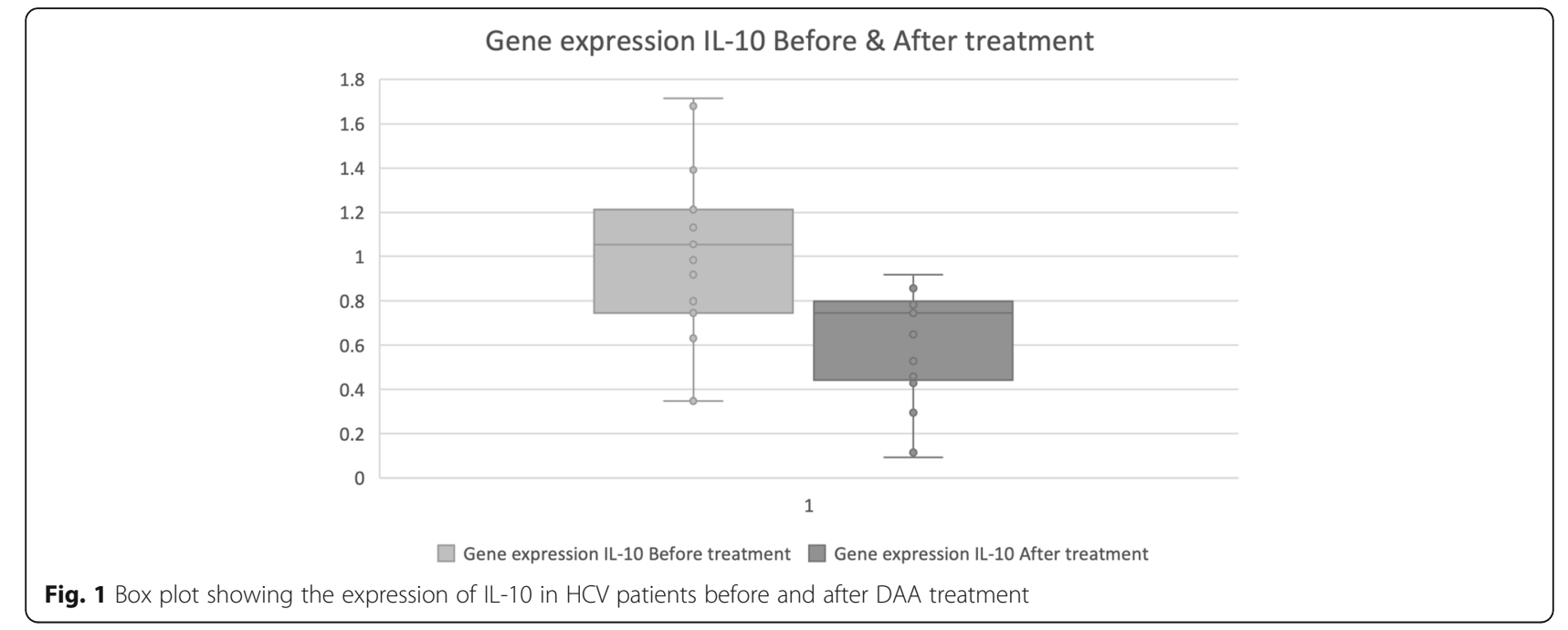

improvement of liver injury, drug side effects or interactions, and treatment response. Typically, SVR is accompanied by normalization of ALT, AST which reflects a positive response to therapy and subsequent reduction in risk for progressive cirrhosis and HCC [31]. In the present study, cases showed normalization of the mean of liver enzymes after treatment. There is a statistically significant difference between the ALT and AST activity before and after treatment. In agreement with these results, Huynh T et al. (2018) [32] assessed the dynamic patterns of both ALT and AST during and after DAA treatment for $\mathrm{HCV}$ infection and the study provided evidence that normalization of both ALT and AST is well associated with sustained HCV clearance and could be a potential biochemical marker to assess $\mathrm{HCV}$ treatment responses. In addition, some authors [31,33] concluded that AST and ALT may serve as a more economical predictive factor for viral clearance for SVR.
Chronic HCV-infected patients are at high risk for development of advanced fibrosis as part of the natural course of the disease, $20 \%$ of patients will progress to advanced liver disease with cirrhosis or HCC [34]. In the present study, $12 \%$ of the cases were categorized by Child-Pugh score as class B while $88 \%$ were classified as class A. Before treatment, APRI index had a mean of 0.87 while the FIB- 4 had a mean of 2.2. After treatment, APRI index showed a mean of 0.44 while the FIB- 4 showed a mean of 1.6. The difference between the APRI score and FIB-4 index before and after treatment was statistically significant.

Bachofner et al. (2017) [35] measured the transient elastography (TE) and calculated the FIB-4 and APRI scores for $549 \mathrm{HCV}$ patients who received a DAA-based treatment and reported that the cases recorded an improvement in liver stiffness recorded by $\mathrm{TE}$ and regression of validated fibrosis scores of the FIB- 4 and APRI in

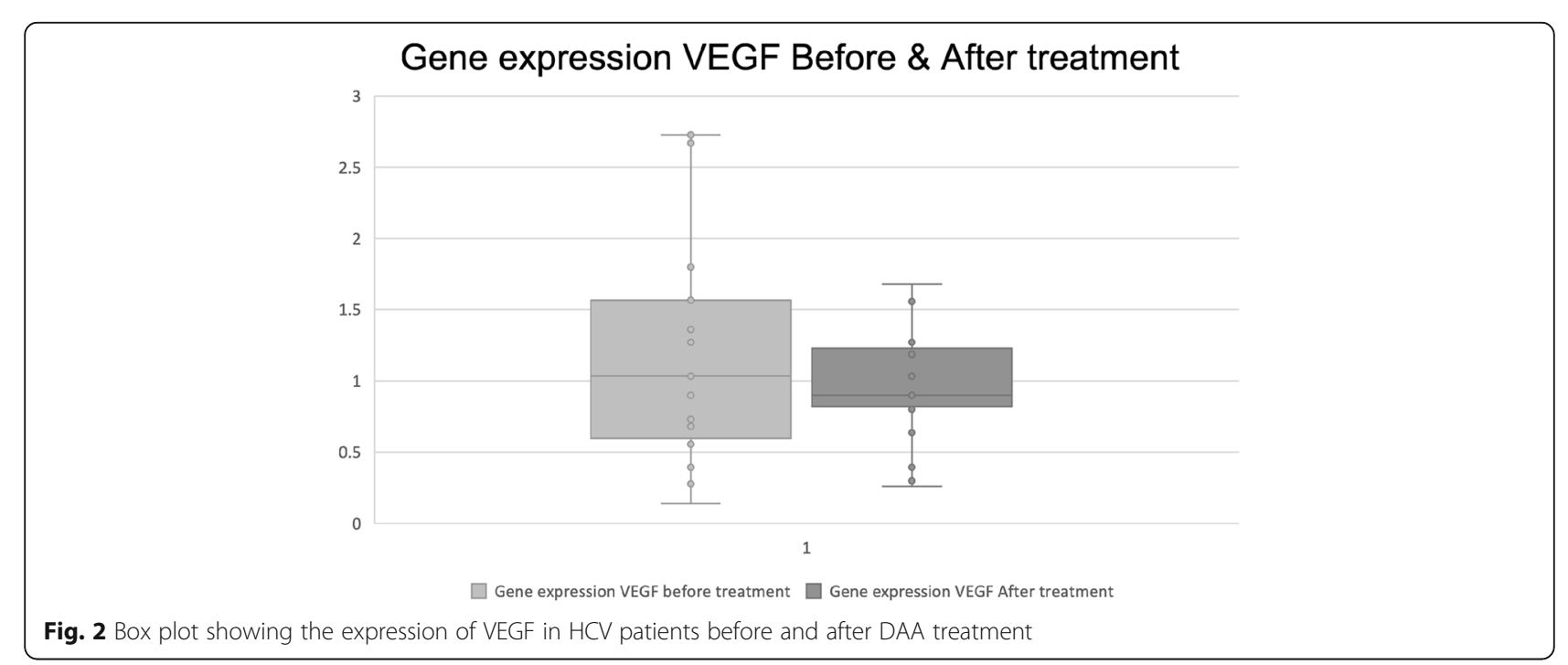


Table $2 \mathrm{IL}-10$ and VEGF gene expression among HCV-infected patients

\begin{tabular}{lll}
\hline Gene expression & Number & $\%$ \\
\hline IL-10 & & \\
$<1$ & 23 & 82 \\
$>1$ & 2 & \\
Range & $0.093-7.345$ & \\
Mean \pm SD & $1.00 \pm 1.50$ & \\
VEGF & & \\
$<1$ & 16 & 36 \\
$>1$ & 9 & \\
Range & $0.258-6.712$ & \\
Mean \pm SD & $1.32 \pm 1.35$ & \\
\hline
\end{tabular}

concordance with the HCV eradication by DAAs. Additionally, Hengst et al. [36] reported a rapid decline in APRI and FIB-4 scores after treatment coinciding with $\mathrm{HCV}$ clearance. Although this study results are in concordance with the previous reported studies but these results raise a question of whether this improvement in liver status reflects a true regression of fibrosis or merely resolution of chronic liver inflammation as the course of improvement is too short for such significant remodeling in liver tissue and such improvement requires longterm follow-up to confirm it.

Several studies addressed the effect of DAAs on the host immune response indicating the reconstitution of innate immunity and downregulation of interferon (IFN) cell signaling after DAA treatment suggesting that the rapid reduction in viremia induced by DAAs may attenuate inflammation with minimizing effects on hepatitis progression [37].

The aim of the present study was to investigate the effect of DAAs on VEGF and IL-10 expression coinciding with the viral clearance. The information on the expression of VEGF and IL-10 mRNA is still incomplete and it has not yet been determined in cases of HCV genotype4 under DAAs treatment which makes the approach of this study a novel one since other studies used the protein serum level $[38,39]$.

In the present study, the gene expression of IL-10 in $\mathrm{HCV}$ genotype-4 patients before and by the end of treatment with DAAs drugs was measured. IL-10 expression was downregulated in $92 \%(23 / 25)$ of the cases, while $8 \%$ $(2 / 25)$ of the cases were upregulated with a range from 0.093 to 7.345. Despite of the apparent differences in expression levels within the studied group, the majority of the cases showed IL-10 down expression after DAA treatment coinciding with the viral clearance which can be explained by improvement of the inflammatory process ongoing with the persistent $\mathrm{HCV}$ infection and normalization of the liver functions. As for 2 cases who showed upregulation of IL-10 expression, they had the highest viral load of all the studied cases which may explain the delay in normalization of the immune response due the possible larger burden of the high viral load on the immune system of these 2 cases.

In this study, the data was grouped according to viral and host factors that influence or reflect progression of the disease, i.e., HCV RNA load, ALT, AST, and the stage of fibrosis. Before treatment, IL-10 showed a positive correlation with the HCV viral load which coincides with the previously mentioned reports linking high HCV replication with upregulation of IL-10 explained by inhibition effector $\mathrm{T}$ cell responses.

Several studies investigated the hypothesis that DAAs may modify the inflammatory pattern along the course of treatment. Saraiva et al. (2018) [40]; studied the dynamics of 30 different circulating cytokines and growth factors in $\mathrm{HCV}$ patients before DAA therapy initiation

Table 3 Correlation between IL-10 and VEGF gene expression with other studied variables before and after DAA treatment

\begin{tabular}{|c|c|c|c|c|c|c|c|c|}
\hline & \multicolumn{4}{|l|}{ IL10 gene expression } & \multicolumn{4}{|l|}{ VEGF gene expression } \\
\hline & \multicolumn{2}{|l|}{ Before treatment } & \multicolumn{2}{|l|}{ After treatment } & \multicolumn{2}{|l|}{ Before treatment } & \multicolumn{2}{|l|}{ After treatment } \\
\hline & Pearson correlation & $p$ value & Pearson correlation & $p$ value & Pearson correlation & $p$ value & Pearson correlation & $p$ value \\
\hline ALT & -0.205 & 0.325 & -0.128 & 0.551 & 0.361 & 0.076 & 0.280 & 0.184 \\
\hline AST & -0.192 & 0.358 & -0.172 & 0.421 & $0.573^{* *}$ & 0.003 & 0.269 & 0.204 \\
\hline Albumin & -0.041 & 0.846 & 0.050 & 0.813 & 0.060 & 0.775 & -0.248 & 0.232 \\
\hline Total bilirubin & 0.051 & 0.809 & -0.237 & 0.265 & -0.035 & 0.868 & -0.068 & 0.754 \\
\hline Direct bilirubin & -0.004 & 0.986 & -0.228 & 0.284 & -0.173 & 0.409 & -0.227 & 0.286 \\
\hline PT (INR) & 0.005 & 0.983 & 0.133 & 0.525 & -0.032 & 0.881 & -0.103 & 0.624 \\
\hline PLT & -0.158 & 0.451 & -0.147 & 0.484 & 0.110 & 0.600 & 0.189 & 0,365 \\
\hline ASPRI & 0.047 & 0.822 & 0.114 & 0.597 & 0.272 & 0.189 & -0.061 & 0.777 \\
\hline FIB-4 & 0.045 & 0.829 & 0.078 & 0.718 & 0.134 & 0.524 & -0.035 & 0.873 \\
\hline
\end{tabular}

*Statistically significant at $p \leq 0.05$ 
and after the end of therapy. The study concluded that there was a decrease in IL-10 serum levels in association with viral clearance after DAA therapy suggesting that it could be explained by loss of the suppressive function of regulatory $\mathrm{T}$ cells (Treg) which secrets IL-10 and other anti-inflammatory cytokines. Also, Villani et al. [41]; confirmed that DAAs resulted in a very rapid decline in viremia and normalization of ALT in less than 4 weeks; together with remarkable decrease in serum IL-10 coinciding with the viral clearance indicating a systemic inflammatory pattern change occurring in chronic $\mathrm{HCV}$ patients with very long lasting inflammation. Moreover, Alhetheel et al. [42] reported that following successful treatment with DAAs, the IL-10 levels declined with a concomitant increase in the serum IL-12 levels.

On the other hand, Hengst et al. [36] study showed that treatment with DAAs showed a dramatic response in clearance of the viral load and normalization of ALT but the studied cytokines (including IL-10) showing a baseline increase in expression although had significantly decreased during and after therapy but they did not completely reach normal values suggesting that the inflammatory changes are not fully reversible upon viral clearance.

These conflicting results in literature could be attributed to the differences in the ability of each patient to trigger an efficient immune response against $\mathrm{HCV}$ infection. In addition, age, gender, viral load, and liver disease status are also considered interference factors in $\mathrm{HCV}$ infection pathogenesis and response of the immune system to treatment. Also, longer follow-up is required to answer the important question of whether the inflammatory parameters will further decline over time in successfully treated patients with $\mathrm{HCV}$ infection and whether long-term restoration of the interferon system is achieved after HCV clearance [43].

In the present study, the hypothesis that DAAs cause an increase in VEGF which may be a risk factor for HCC development was addressed. By evaluating the serum expression of VEGF before and after DAA treatment in our cohort of HCV genotype-4 patients, VEGF expression was heterogeneous showing spreading of values along a wide range showing 64\% (16/25) of the cases being downregulated, while $36 \%(9 / 25)$ of the cases were upregulated. This heterogeneity can be explained by variability in the immune response among the studied patients; although all patients were chronically infected with $\mathrm{HCV}$, but they differed in many ways as the duration of illness, clinical stage of the disease, host genetic, and immune background. Moreover, further follow-up for this group was performed clinically by doing ultrasound at least once after end of treatment and none showed any detectable masses through the period of follow-up (6 months). A positive correlation was found between VEGF expression and each of the viral load as well as AST activity.

Up to our knowledge, only a limited number of studies have been performed to investigate effect of DAAs on different cytokines and growth factors but none of these studies has evaluated the expression level in the setting of follow-up study along the course of DAA treatment as the present study. Different researchers investigated the assumption that treatment with DAA increases the risk for occurrence/recurrence of HCC.

Saraiva et al. in 2018 [40] investigated the circulating levels of inflammatory and profibrogenic cytokines (including VEGF) in 88 patients before and after the end of treatment with DAAs. Serum level of VEGF was increased in HCV-infected patients before treatment while there was a significant decrease after anti-viral therapy. The final conclusion of the study suggested that viral control induced by DAA therapy restores inflammatory mediators in association with improvement in liver function. Similarly, Hengst et al. [36] showed that the expression of VEGF was significantly higher in all patients before treatment which normalized by end of treatment.

On the other hand, Debes et al. [44] in 2018 evaluated serum levels of 52 immune mediators (including cytokines, growth factors, and apoptosis markers) before, during, and after DAA treatment. VEGF-A which showed significantly higher serum expression levels before DAA treatment in patients that later developed HCC. These results potentially suggest that immune modulation by DAA probably does not trigger HCC development but rather that the immune background could be already affected before DAA treatment and induced a carcinogenic or pre-carcinogenic activity. Kawaguchi et al. [45] in 2018 reported that VEGF was continuously rising and maintained a high level until 12 weeks after DAA treatment ended in patient that showed rapidly growing $\mathrm{HCC}$ after treatment. Villani et al. [41] measured the pattern of change in VEGF which showed a 4-fold increase at week 4 after start of DAA treatment and remained elevated up to the end of treatment. The study concluded that the increase of VEGF and change in the inflammatory pattern may alter the balance between inflammatory and antiinflammatory processes and modify anti-tumor surveillance in the host.

The increased risk for $\mathrm{HCC}$ reported by the previous studies was explained by the fact that DAA-mediated clearance of HCV leads to loss of intrahepatic immune activation by IFN- $\alpha$ which activates immune cells as natural killer cells and macrophages that directly inhibits tumor cell proliferation. Consequently, loss of immune activation of these cells by IFN- $\alpha$ may allow tumor growth [46]. However, there are no robust preclinical studies to support this hypothesis. Additionally, even 
using the best imaging modality cannot exclude a small HCC mass before treatment with certainty [47].

A moderate positive correlation between IL-10 and VEGF genes was shown in the studied group which was statistically significant. IL-10 and VEGF have some similarities and overlap in various functions as the processes of inflammation and angiogenesis are intimately linked, inflammatory mediators have a significant effect on the process of angiogenesis, and the reverse is also true [48].

\section{Conclusion}

DAAs has shown excellent SVR in HCV genotype-4 patients reaching $100 \%$ in this study which is associated with improvement in the liver functions and fibrosis scores indicating an improvement in liver inflammation and progression of fibrosis. The relative expression of IL-10 has shown a strong positive correlation with the viral load and data from this study provide evidences that successful viral clearance induced by DAAs leads to the downregulation of IL-10 expression in the majority of cases that could be explained by a possible shift in the pretreatment Th2 dominant immune response to the Th1 response. Despite of the viral clearance, relative expression VEGF was heterogeneous although showed a positive correlation with IL-10 but the upregulation in its expression after treatment in a considerable fraction of patients in this study shows that DAAs do not completely reverse the immunological imprints established upon chronic $\mathrm{HCV}$ infection. Another investigation at the SVR or even later may be needed to determine sustained outcome of the DAA therapy on the immunological response of chronic $\mathrm{HCV}$-infected patients.

\section{Abbreviations}

HCV: Hepatitis C virus; IL-10: Interleukin-10; VEGF: Vascular epidermal growth factor; HCC: Hepatocellular carcinoma; Th1: T helper 1; Th2: T helper 2; TNFa: Tumor necrosis factor-alpha; NK cells: Natural killer; DAA: Directly acting agents; PCR: Polymerase chain reaction; PBMC: Peripheral blood mononuclear cells; FIB-4: Fibrosis-4 index; APRI: Platelet ratio index; PKC: Protein kinase C; MAPK: Mitogen activated protein kinase; SVR: Sustained virological response; IFN: Interferon; Treg: Regulatory T cells; TE: Transient elastography; AST: Aspartate transaminase; ALT: Alanine aminotransferase; NS: Non-structural protein

\section{Acknowledgements}

Not applicable

\section{Authors' contributions}

IN supervised and helped perform all the practical work including determination of HCV viral load, HCV genotyping, and genes expression, as well as writing, revising, and editing the manuscript. AK supervised all the work and helped in data interpretation. SO provided all patients' clinical information and physical examination. HE was performed the practical work. RE supervised all the work. All authors read and approved the final manuscript.

\section{Funding}

The authors declare that there was no funding
Availability of data and materials

Data sharing is not applicable to this article as no datasets were generated or analyzed during the current study.

\section{Declarations}

Ethics approval and consent to participate

Medical research Institute Ethics Committee IORG\#: IORG0008812

The Medical Research Institute-Alexandria University Ethics Committee reviewed the documents for the above-mentioned study. On 8/5/2017, they granted approval for the above mentioned study to be conducted at the Medical Research Institute-Alexandria University.

The ethics committee of the Medical Research Institute-Alexandria University is constituted and operating according to ICH GCP guidelines and applicable local and institutional regulations and guidelines which govern IRB operation. Informed written consent was taken from each patient.

\section{Consent for publication}

Not applicable.

\section{Competing interests}

The authors declare that they have no competing interests.

\section{Author details}

${ }^{1}$ Department of Microbiology, Medical Research Institute, University of Alexandria, Alexandria, Egypt. ${ }^{2}$ Department of Chemical Pathology, Medical Research Institute, University of Alexandria, Alexandria, Egypt. ${ }^{3}$ Department of Experimental and Clinical Internal Medicine, Medical Research Institute, University of Alexandria, Alexandria, Egypt.

Received: 7 December 2020 Accepted: 3 May 2021

Published online: 12 May 2021

References

1. Buonfiglioli F, AP CF, Crespi C, Foschi FG, Lenzi M et al (2016) Development of hepatocellular carcinoma in HCV cirrhotic patients treated with direct acting antivirals. Annual Meeting of EASL, Barcelona

2. Elgharably A, Gomaa Al, Crossey MM, Norsworthy PJ, Waked I, TaylorRobinson SD (2017) Hepatitis C in Egypt - past, present, and future. Int J Gen Med 10:1-6. https://doi.org/10.2147/IJGM.S119301

3. Messina JP, Humphreys I, Flaxman A, Brown A, Cooke GS, Pybus OG, Barnes E (2015) Global distribution and prevalence of hepatitis $C$ virus genotypes. Hepatology. 61(1):77-87. https://doi.org/10.1002/hep.27259

4. Kouyoumjian SP, Chemaitelly H, Abu-Raddad LJ (2018) Characterizing hepatitis C virus epidemiology in Egypt: systematic reviews, meta-analyses, and meta-regressions. Sci Rep 8(1):1661. https://doi.org/10.1038/s41598-01 7-17936-4

5. Li K, Lemon SM (2013) Innate immune responses in hepatitis C virus infection. Semin Immunopathol 35(1):53-72. https://doi.org/10.1007/s00281012-0332-x

6. Zekri A-RN, Ashour MSE-D, Hassan A, Alam El-Din HM, El-Shehaby AMR, Abu-Shady MA (2005) Cytokine profile in Egyptian hepatitis C virus genotype-4 in relation to liver disease progression. World J Gastroenterol 11(42):6624-6630. https://doi.org/10.3748/wjg.v11.i42.6624

7. Bruno CM, Valenti M, Bertino G, Ardiri A, Amoroso A, Consolo M, Mazzarino CM, Neri S (2011) Relationship between circulating interleukin-10 and histological features in patients with chronic C hepatitis. Ann Saudi Med 31(4):360-364. https://doi.org/10.4103/0256-4947.83215

8. Wilson EB, Brooks DG (2011) The role of IL-10 in regulating immunity to persistent viral infections. Curr Top Microbiol Immunol 350:39-65. https:// doi.org/10.1007/82_2010_96

9. El-Emshaty HM, Nasif WA, Mohamed IE (2015) Serum cytokine of IL-10 and IL-12 in chronic liver disease: the immune and inflammatory response. Dis Markers 2015:707254

10. Ejrnaes M, Filippi CM, Martinic MM, Ling EM, Togher LM, Crotty S, von Herrath MG (2006) Resolution of a chronic viral infection after interleukin-10 receptor blockade. J Exp Med 203(11):2461-2472. https://doi.org/10.1084/ jem.20061462

11. Taktak-BenAmar A, Morjen M, Ben Mabrouk H, Abdelmaksoud-Dammak R, Guerfali M, Fourati-Masmoudi N et al (2017) Expression, purification and 
functionality of bioactive recombinant human vascular endothelial growth factor VEGF(165) in E. coli. AMB Express 7(1):33

12. Koch $S$, Claesson-Welsh L (2012) Signal transduction by vascular endothelial growth factor receptors. Cold Spring Harb Perspect Med 2(7):a006502. https://doi.org/10.1101/cshperspect.a006502

13. Mee CJ, Harris HJ, Farquhar MJ, Wilson G, Reynolds G, Davis C, van IJzendoorn SCD, Balfe P, McKeating JA (2009) Polarization restricts hepatitis C virus entry into HepG2 hepatoma cells. J Virol 83(12):6211-6221. https:// doi.org/10.1128/JVI.00246-09

14. Llovet JM, Pena CE, Lathia CD, Shan M, Meinhardt G, Bruix J (2012) Plasma biomarkers as predictors of outcome in patients with advanced hepatocellular carcinoma. Clin Cancer Res 18(8):2290-2300. https://doi.org/1 0.1158/1078-0432.CCR-11-2175

15. Hepatitis C (2018) Guidance 2018 update: AASLD-IDSA recommendations for testing, managing, and treating hepatitis $C$ virus infection. Clin Infect Dis 67(10):1477-1492

16. WHO (2016) WHO guidelines for the screening care and treatment of persons with chronic hepatitis C infection. World Health Organization, Geneva, pp 25-26

17. Doumas BT, Watson WA, Biggs HG (1971) Albumin standards and the measurement of serum albumin with bromcresol green. Clin Chim Acta 31(1):87-96. https://doi.org/10.1016/0009-8981(71)90365-2

18. Jendrassik LGP (1938) Vereinfachte photometrische Methode zur Bestimmung des Bilirubins. Biochem Z 297:81-89

19. Bergmeyer HU, Horder M, Rej R (1986) International Federation of Clinical Chemistry (IFCC) scientific committee, analytical section: approved recommendation (1985) on IFCC methods for the measurement of catalytic concentration of enzymes. Part 3. IFCC method for alanine aminotransferase (L-alanine: 2-oxoglutarate aminotransferase, EC 2.6.1.2). J Clin Chem Clin Biochem 24(7):481-495

20. Rej R (1984) Measurement of aminotransferases: part 1. Aspartate aminotransferase. Crit Rev Clin Lab Sci 21(2):99-186. https://doi.org/10.31 09/10408368409167137

21. Lewis SMBB, Bates I (2017) Chapter 16:investigation of haemostsis (CBC, PT, INR). In: Dacie and Lewis practical Haematology, 12th edn. J and Churchil Elsevier Ltd, Philadelphia, pp 389-391

22. Halfon $P$, Bourlière $M$, Pénaranda $G$, Khiri $H$, Ouzan D (2006) Real-time PCR assays for hepatitis $\mathrm{C}$ virus (HCV) RNA quantitation are adequate for clinical management of patients with chronic HCV infection. J Clin Microbiol 44(7): 2507-2511. https://doi.org/10.1128/JCM.00163-06

23. Kuang J, Yan X, Genders AJ, Granata C, Bishop DJ (2018) An overview of technical considerations when using quantitative real-time PCR analysis of gene expression in human exercise research. PLoS One 13(5):e0196438 Available from: http://europepmc.org/abstract/MED/29746477. https://doi. org/10.1371/journal.pone.0196438, http://europepmc.org/articles/PMC5944 930 http://europepmc.org/articles/PMC5944930?pdf=render

24. Livak KJ, Schmittgen TD (2001) Analysis of relative gene expression data using real-time quantitative PCR and the 2(-Delta Delta $C(T))$ method. Methods. 25(4):402-408. https://doi.org/10.1006/meth.2001.1262

25. WHO (2018) Guidelines for the Care and Treatment of Persons Diagnosed with Chronic Hepatitis C Virus Infection [Internet] Geneva: WHO

26. Horsley-Silva JL, Vargas HE (2017) New therapies for Hepatitis C virus infection. Gastroenterol Hepatol (N Y) 13(1):22-31

27. El Raziky MGM, Hammad R (2015) Treatment of hepatitis C genotype 4 patients with simeprevir and sofosbuvir: preliminary results from a phase lla, partially randomised, open-label trial conducted in Egypt (OSIRIS). Hepatology 62(1):145A

28. Lawitz E, Poordad F, Brainard DM, Hyland RH, An D, Dvory-Sobol H, Symonds WT, McHutchison JG, Membreno FE (2015) Sofosbuvir with peginterferon-ribavirin for 12 weeks in previously treated patients with hepatitis C genotype 2 or 3 and cirrhosis. Hepatology. 61(3):769-775. https://doi.org/10.1002/hep.27567

29. Feld JJ, Jacobson IM, Hezode C, Asselah T, Ruane PJ, Gruener N et al (2015) Sofosbuvir and Velpatasvir for HCV genotype 1, 2, 4, 5, and 6 infection. N Engl J Med 373(27):2599-2607. https://doi.org/10.1056/NEJMoa1512610

30. Gayam V, Khalid M, Mandal AK, Hussain MR, Mukhtar O, Gill A, Garlapati P, Shrestha B, Guss D, Sherigar J, Mansour M, Mohanty S (2018) Direct-acting antivirals in chronic hepatitis c genotype 4 infection in community care setting. Gastroenterology Res 11(2):130-137. https:/doi.org/10.14740/gr999w

31. Chatterjee M, Anju CP, Biswas L, Anil Kumar V, Gopi Mohan C, Biswas R (2016) Antibiotic resistance in Pseudomonas aeruginosa and alternative therapeutic options. Int J Med Microbiol 306(1):48-58. https://doi.org/10.101 6/.jijmm.2015.11.004

32. Huynh T, Zhang J, Hu KQ (2018) Hepatitis C virus clearance by direct-acting antiviral results in rapid resolution of hepatocytic injury as indicated by both alanine aminotransferase and aspartate aminotransferase normalization. J Clin Transl Hepatol 6(3):258-263. https://doi.org/10.14218/JCTH.2018.00014

33. Khan ST, McGuinty M, Corsi DJ, Cooper CL (2017) Liver enzyme normalization predicts success of Hepatitis $\mathrm{C}$ oral direct-acting antiviral treatment. Clin Invest Med 40(2):E73-e80

34. Yen Y-H KF-Y, Kee K-M, Chang K-C, Tsai M-C, Hu T-H et al (2018) APRI and FIB-4 in the evaluation of liver fibrosis in chronic hepatitis C patients stratified by AST level. PLoS One 13(6):e0199760. https://doi.org/10.1371/ journal.pone.0199760

35. Bachofner JA, Valli PV, Kroger A, Bergamin I, Kunzler P, Baserga A et al (2017) Direct antiviral agent treatment of chronic hepatitis $C$ results in rapid regression of transient elastography and fibrosis markers fibrosis-4 score and aspartate aminotransferase-platelet ratio index. Liver Int 37(3):369-376. https://doi.org/10.1111/liv.13256

36. Hengst J, Falk CS, Schlaphoff V, Deterding K, Manns MP, Cornberg M, Wedemeyer H (2016) Direct-acting antiviral-induced hepatitis c virus clearance does not completely restore the altered cytokine and chemokine milieu in patients with chronic hepatitis C. J Infect Dis 214(12):1965-1974. https://doi.org/10.1093/infdis/jiw457

37. Meissner EG, Lee YJ, Osinusi A, Sims Z, Qin J, Sturdevant D, McHutchison J, Subramanian M, Sampson M, Naggie S, Patel K, Remaley AT, Masur H, Kottilil $S$ (2015) Effect of sofosbuvir and ribavirin treatment on peripheral and hepatic lipid metabolism in chronic hepatitis C virus, genotype 1-infected patients. Hepatology. 61(3):790-801. https://doi.org/10.1002/hep.27424

38. Othman MS, Aref AM, Mohamed AA, Ibrahim WA (2013) Serum levels of interleukin-6 and interleukin-10 as biomarkers for hepatocellular carcinoma in Egyptian patients. ISRN Hepatol 2013:412317

39. Yoneda S, Umemura T, Katsuyama Y, Kamijo A, Joshita S, Komatsu M, Ichijo T, Matsumoto A, Yoshizawa K, Ota M, Tanaka E, the Nagano Interferon Treatment Research Group (2011) Association of serum cytokine levels with treatment response to pegylated interferon and ribavirin therapy in genotype 1 chronic hepatitis C patients. J Infect Dis 203(8):1087-1095. https://doi.org/10.1093/infdis/jiq165

40. Saraiva GN, do Rosario NF, Medeiros T, Leite PEC, Lacerda GS, de Andrade TG et al (2018) Restoring inflammatory mediator balance after Sofosbuvirinduced viral clearance in patients with chronic Hepatitis C. Mediat Inflamm 2018:8578051

41. Villani R, Facciorusso A, Bellanti F, Tamborra R, Piscazzi A, Landriscina M, Vendemiale G, Serviddio G (2016) DAAs rapidly reduce inflammation but increase serum VEGF level: a rationale for tumor risk during anti-HCV treatment. PLoS One 11(12):e0167934. https://doi.org/10.1371/journal.pone. 0167934

42. Alhetheel A, Albarrag A, Shakoor Z, Alswat K, Abdo A, Al-Hamoudi W (2016) Assessment of pro-inflammatory cytokines in sera of patients with hepatitis C virus infection before and after anti-viral therapy. J Infect Dev Ctries 10(10):1093-1098. https://doi.org/10.3855/jidc.7595

43. Carlin AF, Aristizabal P, Song Q, Wang H, Paulson MS, Stamm LM, Schooley RT, Wyles DL (2015) Temporal dynamics of inflammatory cytokines/ chemokines during sofosbuvir and ribavirin therapy for genotype 2 and 3 hepatitis C infection. Hepatology. 62(4):1047-1058. https://doi.org/10.1002/ hep. 27971

44. Debes JD, van Tilborg M, Groothuismink ZMA, Hansen BE, Schulze Zur Wiesch J, von Felden J et al (2018) Levels of cytokines in serum associate with development of hepatocellular carcinoma in patients with HCV infection treated with direct-acting antivirals. Gastroenterology 154(3):515-7. e3

45. Kawaguchi T, Ide T, Koga H, Kondo R, Miyajima I, Arinaga-Hino T, Kuwahara R, Amano K, Niizeki T, Nakano M, Kuromatsu R, Torimura T (2018) Rapidly growing hepatocellular carcinoma after direct-acting antiviral treatment of chronic hepatitis C. Clin J Gastroenterol 11(1):69-74. https://doi.org/10.1007/ s12328-017-0789-1

46. Serti E, Chepa-Lotrea X, Kim YJ, Keane M, Fryzek N, Liang TJ et al (2015) Successful interferon-free therapy of chronic hepatitis $C$ virus infection normalizes natural killer cell function. Gastroenterology 149(1):190-200.e2

47. Faillaci F, Marzi L, Critelli R, Milosa F, Schepis F, Turola E, Andreani S, Vandelli G, Bernabucci V, Lei B, D'Ambrosio F, Bristot L, Cavalletto L, Chemello L, Sighinolfi P, Manni P, Maiorana A, Caporali C, Bianchini M, Marsico M, Turco 
L, de Maria N, del Buono M, Todesca P, di Lena L, Romagnoli D, Magistri P, di Benedetto F, Bruno S, Taliani G, Giannelli G, Martinez-Chantar ML, Villa E (2018) Liver angiopoietin-2 is a key predictor of de novo or recurrent hepatocellular cancer after hepatitis $\mathrm{C}$ virus direct-acting antivirals. Hepatology. 68(3):1010-1024. https://doi.org/10.1002/hep.29911

48. Park MS, Kim S, Patel J, Hajdu CH, Do RK, Mannelli L et al (2012)

Hepatocellular carcinoma: detection with diffusion-weighted versus contrast-enhanced magnetic resonance imaging in pretransplant patients. Hepatology. 56(1):140-148. https://doi.org/10.1002/hep.25681

\section{Publisher's Note}

Springer Nature remains neutral with regard to jurisdictional claims in published maps and institutional affiliations.

Submit your manuscript to a SpringerOpen ${ }^{\circ}$ journal and benefit from:

- Convenient online submission

- Rigorous peer review

- Open access: articles freely available online

- High visibility within the field

- Retaining the copyright to your article

Submit your next manuscript at $\boldsymbol{\sim}$ springeropen.com 